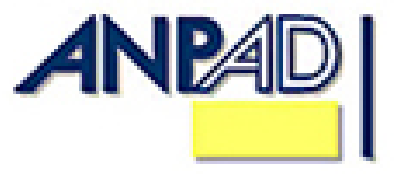

Available online at http://www.anpad.org.br/bar

BAR, Rio de Janeiro, v. 9, n. 1, art. 2, pp. 23-43, Jan./Mar. 2012

\title{
A Socio-Environmental Development Programme in Action in Brazilian Amazonia
}

Ana Maria de Albuquerque Vasconcellos *

E-mail address: annavasc@unama.br Universidade da Amazônia - UNAMA

Belém, PA, Brazil.

Mário Vasconcellos Sobrinho E-mail address: mariovasc@ufpa.br Universidade Federal do Pará - NUMA/UFPA, Universidade da Amazônia - UNAMA Belém, PA, Brazil.

* Corresponding author: Ana Maria de Albuquerque Vasconcellos Universidade da Amazônia, Núcleo Socioeconômico, Av. Alcindo Cacela, 287, Umarizal, Belém, PA, 66060902, Brazil.

Copyright (C) 2012 Brazilian Administration Review. All rights reserved, including rights for translation. Parts of this work may be quoted without prior knowledge on the condition that the source is identified. 


\begin{abstract}
This paper deals with the process of scaling up and scaling down grassroots demands through a state-sponsored socio-environmental development programme in Brazilian Amazonia called Proambiente (Pro-environment). The paper attempts to understand the links between the three different levels of the programme actions: the macro (federal government), intermediate (NGOs), and local (community) levels. The central paper's issue is to understand how a state-sponsored socio-environmental development programme interacts with and impacts local communities. The theoretical paper's framework involves the approaches of participatory development and governance. The methodology is based on three levels of qualitative analysis (macro-, intermediary- and locallevel). The paper (a) describes the trajectory of the Proambiente and the process of scaling up communities' demands; (b) reveals contradictions within the Proambiente implementation; and (c) debates the impacts of the programme actions at local level. The paper reveals that once the state encompasses local people's demands and creates a development programme, the development model absorbs multi-actor interests that change local people's proposals. It also shows that the challenge facing a socio-environmental development programme like the Proambiente is to find a balance between production and conservation aims.
\end{abstract}

Key words: governance; development programme; Amazonia; proambiente. 


\section{Introduction}

This paper is about the process of scaling up and scaling down grassroots demands through a socio-environmental development programme. The paper seeks to show how demands from the grassroots level have scaled up to public policy, changed, and then scaled down to the local communities. The central question is: how does a socio-environmental development programme using a popular participation approach, sponsored and carried out by the federal government, and intermediated by NGOs - interact with and impact local communities?

The hypothesis is that once a state-sponsored programme interacts with local communities through the participation approach, it acknowledges local people's demands. However, when local people's demands scale up to public policy, the programme changes local people's proposals and scales down; taking actions that prioritise state interests rather than local people's proposals.

The paper explains the ways in which local communities are linked with actions of a programme that approaches participatory development. In the context of this paper, scaling up is understood as a process of incorporation and prioritisation of grassroots demands in this socioenvironmental development programme and its subsequent use in public policy. Scaling down is the process of change in public policy and socio-environmental development programme aims, resulting in practical actions at the local level that impact rural communities.

The paper is based on the Brazilian federal socio-environmental programme called Proambiente (Social and Environmental Development Programme for Rural Family-based Production). This programme was chosen as the case study because it is an attempt by the Brazilian federal government to use participatory approaches to incorporate rural communities' demands, culture, and knowledge into a development programme in Brazilian Amazonia. The Proambiente tries to promote productive conservation in the Brazilian Amazonia, paying family-based, small-scale producers to conserve natural resources such as forests and streams. The aim of the Proambiente is to set up a multifunctional model of development that links economic growth, social inclusion and environmental conservation (Ministério do Meio Ambiente [MMA], 2005) in rural communities. The core objectives of the programme are: (a) to support family-based, rural producers to convert the traditional'slash and burn' agricultural practices that currently prevail in Amazonia into more diversified and sustainable agricultural and extractive practices and consequently; (b) to facilitate compensation for environmental services rendered to Brazil and the world (Hall, 2008). The Proambiente model uses poles (a set of counties - municipios), counties (municípios) and rural communities. Due to the scale and complexity of the programme, only one pole was selected for examination in this paper: the pole of Rio Capim, in the state of Pará. Its communities have distinct social, cultural, and environmental characteristics that demonstrate the diversity of Brazilian Amazonia. The objective to look at the Rio Capim pole was to examine the problems faced by the Proambiente's managers to carry out the programme actions at the local level while taking into account local, rural knowledge and culture.

The paper contributes to the debate towards transforming political culture to reverse top-down policies. It also contributes to the identification of the construction of a new space of policy action through the interaction between government, NGO, and the local community. Empirically, the paper contributes to the current body of knowledge in three ways: First, by the identification of the trajectory of the peasant social movement as a significant background to understand a socio-environmental development programme model in Brazilian Amazonia. Second, the recognition of the social network as an important mechanism to exert pressure on government to support local people's knowledge and cultural identity. Third, the identification of the strategies to reverse predominantly top-down policies through the encouragement of people's participation in a governmental programme. In doing so, the paper is divided into five sections. Following this introduction, the second section takes a critical look at the participatory approach and the relation between macro, intermediary, and micro levels of analysis to evaluate a state-sponsored socio-environmental programme in action. The third section deals with the trajectory of the Proambiente Programme. The aim of the third section is to show the 
trajectory of the Proambiente and the process of scaling up communities' demands. The fourth section debates the impacts of the programme actions at the local level, particularly on the communities of the Rio Capim pole. The section's aim is to show how the programme interacts and impacts the rural communities through the process of scaling down. Finally, the last section has significant conclusions about the way which state and rural communities interact with each other during the process of a statesponsored socio-environmental programme, both throughout its implementation and regarding the Proambiente programme itself.

\section{Relevance of Different Levels of Analysis to Evaluate a State-sponsored Socio- environmental Programme in Action}

The participatory approach is related in a complex model of interaction (Arce, 2003; Edwards \& Hulme, 2000; Milani, 2008; Rodriguez et al., 2007) at the macro, intermediary and micro levels. Booth (2003), for example, identifies the existence of two traditions of research that are becoming visible in the analysis of social development processes. First, there is the macro-level tradition of working downwards from the national level to particular institutions and programmes; and second, the micro-level tradition, like the actor-oriented approach, working upwards from the level of individual actions (Booth, 2003). The analysis of the interaction among the notions of micro and macro levels explores how social reality is constituted in development processes (Arce, 2003; Berkhout et al., 2010; Edwards \& Hulme, 2000). It implies that the macro-micro interaction makes development studies relevant, especially regarding the ways in which local people and policies come together.

The intermediary level is seen as a space for NGOs to open up channels for participation and changes of governance structures in favour of democratisation (Edwards \& Hulme, 2000; Fowler, 2002; Tendler, 1997). In this way, the NGOs are singled out as important intermediary organisations to help strengthen sectors of civil society so they become more potent political forces in their own right and engage in policy advocacy in both national and international forums. However, on a regular basis NGOs have difficulty in interacting effectively with social, economic, and political matter at national and international levels (Edwards \& Hulme, 2000). Faced with this, NGOs are reflecting upon their future roles and effectiveness, and are experimenting with a range of strategies to increase, or scale up, the impact of their development work (Edwards \& Hulme, 2000).

NGOs play a key role at the intermediary level as they bring with them a certain amount of autonomy to promote encounters with state institutional structures (Clark, 1997). However, NGOs depend on their connections with, or usefulness for, local constituencies (Edwards \& Hulme, 1997, 2000). They are conceptualised as a space where interfaces between administrative policies and peoples' courses of action take place, and as a location where different agents encounter one another (Arce, 2003; Clark, 1997).

From Arce's (2003) point of view, analysis of the intermediary level is a fundamental way to go beyond notions of micro and macro levels of analysis. Arce (2003) argues for the metaphor of the middle ground to understand local interactions and to provide a way to visualise social relations. The metaphor of the middle ground attempts to re-conceive the context of social ordering and the interpretation of local interactions through the construction of objects of examination. The middle ground helps to identify how development policies are used for intervening in people's social relations; a process which can generate new collective representations (Edwards \& Hulme, 2000). An important element that has contributed to building up the metaphor of the middle ground is how the reconceptualisation of micro and macro traditions in relation to an organizing context, carries policy into society (Arce, 2003).

Mayoux and Chambers (2005) state the importance of congruence from the bottom up. Culture, institutions, procedures, and relationships at the middle and upper-level of an organisation should be congruent with and support those at the grassroots. Mayoux and Chambers (2005) also argue that 
many bureaucrats and administrators demand a radical reversal of perceptions, attitude, and behaviour to achieve bottom-up congruence. However, the challenge is to promote a congruence of commitment among practices and relationships at all levels. Cultural examination takes into account the interdependence between the social, cultural, economic, and ecological aspects ruling the life of these groups. It means that cultural reality is not isolated. There is a complex interrelation between a group's identity, ecology, social organization, and religious beliefs (Mejía, 2004). Although scientists, practitioners, and governments spend considerable resources on developing and implementing intervention programmes at the community level (Guijt \& Gaventa, 1998; International Union for Conservation of Nature [IUCN], 2008), very little work has been undertaken to explore the strategies that communities use to manage change (Booth, 2003; Brockington, Duffy, \& Igoe, 2008; Plummer, Velaniskis, Grosbois, Kreutzwiser, \& Loe, 2010; Uphoff, Esman, \& Krishna, 1998).

Through community participation, local knowledge, expertise and resources are mobilized and an opportunity is created for forming shared meanings that will increase the chances for the successful implementation of the intervention (Wield, 2003). However, effective participation can only be approached through an understanding of power and its realization in practices that prohibit or promote participation (Gregory, 2000).

A focus on micro-level research is required to understand which forms of participation work in which kinds of spaces to provide people with the opportunity to realise inclusive, active citizenship (Cornwall, 2002). As argued by Feuerstein (1986) and Rebien (1996) there are different forms and degrees of participation that face social, structural and administrative barriers (Guba \& Lincoln, 1989). However, any community project that includes participation of the more vulnerable rural communities should start by reflecting on and stating non-negotiable principles - NNP (Chambers, 2005). Thus, the project may be less exclusive and less threatening to more disadvantaged people. According to Chambers (2005), this is because the definition of an NNP facilitates the achievement of objectives.

\section{Methods of Analysis and Data Gathering}

The macro level of analysis was understood as the Proambiente proposals (and actions) for community development. The intermediate level of analysis included the links between public policy and the Proambiente and their different types of interaction. The micro level of analysis focused on local communities, identifying rural people's expectations for control over the assets of their livelihoods.

The data analysis research on the macro level focused on programme development. It aimed to identify the criteria for choosing the programme focus, the knowledge concepts emphasised for key activities of the programme and methods of the knowledge used in the programme to implement people participation. On this level, the research distinguished between the processes of popular participation in the diverse phases of the programme. This required an identification of the key features that are designed to empower the communities.

At the intermediary level, the research concentrated on the analysis of the NGOs that are building links between the Proambiente and the local communities. The identification of the NGO (FANEP) that has been working at the intermediary level was important to analyse the programme's performance and programme actions at the local level. The sources of information consisted of semistructured interviews with NGO members such as coordinators, managers and agricultural technicians; those directly involved with the Proambiente. There was also secondary material that consisted of analysis of documentation produced by the NGO.

At the micro level of analysis, the research involved community leaders, group leaders, householders, members of local government (prefeituras - mayors and city councils) where the communities are located, members of the Movimento dos Trabalhadores Sem Terra-MST (Landless 
Movement), and members of Sindicatos dos Trabalhadores Rurais - STRs (Rural Workers' Unions). These sources could identify people's expectations of the programme for the improvement of their livelihoods and their knowledge (skills or abilities) about using natural resources.

The research applied documentary analysis, participant observation, focus groups, and unstructured and semi-structured interviews as methods of data gathering. These different methods allowed the researchers to collect data from a triangulation analysis perspective (Patton, 2001).

The documentary analysis consisted of examining programme planning and implementation of all phases of policy actions to link the macro to the micro level. In order to study the process of the Proambiente, a critical approach to the presentation of policy practice was adopted. For this reason, the study reviewed the formal programme documentation and project operations to investigate possible gaps between policy and practice. Sources of information included formal and public documents, such as the various revisions of programme proposals, programme reports, and official submission of NGO reports to policy makers. This level of sources also included other documents from Brazilian government institutions, such as the Ministry of the Environment (MMA) and the Brazilian Institute for the Environment and Renewable Natural Resources (Instituto Brasileiro do Meio Ambiente e Recursos Naturais Renováveis [IBAMA]).

Participant observation took place particularly in the course of PRA (Participatory Rural Appraisal) carried out by FANEP (intermediary ONG) during the workshop for discussion on a community project called PADEQ (Alternatives to Deforestation and Forest Burning Project).

The method of participant observation contributed to a better understanding of the different levels of people's participation in the project design. Observation also contributed to an understanding of the cultural aspects of the communities, such as beliefs, interests, and priorities. It also helped gain knowledge about the social structures of the groups and how they are interrelated within the systems that are set up for them. The PRA exercises conducted by the FANEP during the workshop enabled the researchers to gather detailed information about the programme itself, about the communities' involvement in it, and about people's interests in, and expectations of, the programme. The objective of the FANEP workshops was to develop local planning from the use of participatory methods. This planning aimed to emphasise local people's knowledge, something Chambers (1992) suggests is fundamental for changing priorities. The workshop took place in the community of Vila do Galho and involved at least one leader of each local community of the Rio Capim pole. These leaders were agriculturists, members of the STRs, community leaders, local group leaders, and individuals interested in the subject. Twenty-three leaders participated in all of the workshop events. Others (heads of labour unions, local government representatives) participated just once or twice in different events.

Four focus groups (discussion groups) were carried out by the researchers. The first focus group involved all community leaders of the Rio Capim pole and focused on: (a) the meaning of community; (b) expectations of the participants of their involvement in the different phases of the programme; and (c) expectations of the communities in accessing resources such as payment for environmental services. This focus group was carried out with the participation of 23 people from 13 diverse areas of the pole of Rio Capim.

The second focus group was with women from the county (município) of Concórdia do Pará. The women were prioritised because only five of them had participated in the FANEP workshop and none of them were from Concórdia do Pará. The discussion group aimed to gather data about the women's beliefs, values, needs, and priorities, as well as the women's expectations about the programme. This focus group involved 8 women from 6 communities.

The third focus group was with leaders and households from the county (município) of Concórdia do Pará. It aimed to identify problems encountered inside the communities to carry out the programme actions in the county (município). This focus group was also composed of eight people. 
The fourth focus group was with young people from Vila do Galho (in the county (municipio) of Concórdia do Pará). The researchers found the exclusion of young people from participating in the FANEP workshop a critical issue for the Proambiente. Their values, beliefs, needs, and priorities were not considered in the pole diagnosis. The researchers believed it fundamental to gain information about young people's expectations from the Proambiente and from the communities. Two questions were defined for this focus group: What are the group's priorities? What are the group's objectives for livelihood improvements? This focus group was held only once. The session was composed of eight teenagers and was approximately one hour.

Unstructured and semi-structured interviews were particularly useful to explore specific issues. They were categorised into three levels: macro level (national organisers), intermediate level (regional organisations, NGOs), and micro level (communities). At the macro level, the interviews aimed to identify the background of the Proambiente and the different phases of the programme implementation by focusing on the national programme staff and using semi-structured interviews. These interviews were carried out with two Proambiente co-ordinators and two former co-ordinators (former members of the MMA) totalising four people. At the intermediary level, which comprises the NGOs that link between the federal government and communities of the Proambiente, the interviews concentrated on two agents of the FASE (general coordinator of the NGO and the field manager of Proambiente) and five FANEP agents (coordinator of the NGO, field manager of the Proambiente, manager of the PADEQ project, and two other staff members of the NGO) totalling seven people. At the local level, the unstructured and semi-structured interviews involved four community leaders, one labour union leader, and eight people identified as key informants at the community level (six households and two teachers).

\section{The Trajectory of the Proambiente Programme: from Rural Communities to Public Policy}

Although many factors influenced the Prombiente's creation, three of them were fundamental to its establishment: (a) environmental policy changes within the models implemented for Brazilian Amazonia development; (b) rural social movements in Brazil, Amazonia, and the state of Pará; (c) recent national and regional policies providing financial credit for rural production. In fact, the literature (F. A. Costa, 2005; M. Vasconcellos, 2009) has shown that there is an intersection between the rural social movements, environmental policy changes, and policies of providing financial credit for rural production that resulted in new proposals for communities' development.

There are at least twenty-five years of academic commentary on the history of models for Brazilian Amazonia development at the regional, national, and international levels (Hall, 1991; R. Monteiro, 1996). Though they use different perspectives of analysis, they focus on the same issue: Brazilian models for development. First, they concentrated on the extraction of natural resources (R. Monteiro, 1996; Santos, 1980). Second, they focused on large-scale agricultural production and cattle ranching (Bunker, 1985; Fearnside, 2005; R. Monteiro, 1996). Third, they focused on the exploitation of mineral resources, the implantation of mineral industries, and hydroelectric projects. All caused environmental disruption and social impact.

The first dictatorship model for Amazonia development was based on large-scale agricultural production, agribusiness, and cattle ranching and was linked to two significant programmes: a programme of fiscal incentives and a programme of colonisation and assentamento (human settlement) (Hall, 1991). The first programme attracted medium and well-established businesses from the south and south-east of Brazil interested in expansion, while the latter attracted migrants from the north-east of the country (Brum, 2005). The programme of fiscal incentives for agribusiness facilitated the implantation of large-scale farming that initially impacted the environment through large-scale deforestation. At the same time, wood exploration emerged as a big business. The infrastructure established by colonisation also had an adverse effect on the natural environment. Both programmes 
caused a social impact on the traditional resident population that occupied the land designated for the programmes. In fact, there was a large social and territory reconfiguration in Amazonia (Becker, 2001). Land concentration and the growth of poverty were only two among several other consequences (J. M. M. Costa, 1997; Hall, 1991).

From that time onwards, social conflicts for land occupation and exploration emerged as a huge problem in the region. Directly associated with the phenomenon of land concentration is the growth of rural violence (J. M. M. Costa, 1997; Hall, 1991). The poor infrastructure offered by the federal government in the programmes of assentamento and agribusiness allied with other economic factors encouraged businesses to focus on wood exploration and extraction rather than on agricultural cultivation. It distorted the aim of the programmes and expanded environmental impacts and social conflicts (J. M. M. Costa, 1997).

Environmental and social disruption continued with the exploitation of mineral resources through industrialisation (Fearnside, 2000; M. A. Monteiro, 2005). The industries themselves and the hydroelectric infrastructure built to support industry also required the use of huge areas of land in Amazonia. At present, adverse effects on the natural environment are highly evident through river and air pollution and decreasing fish stocks, all depleting the once noble jungle and regional forest resources (Fearnside, 2006; M. A. Monteiro, 2005).

During the 1980s, Brazilian Amazonia faced three great environmental problems from the patterns of development implemented by the military government and continued by the first postdictatorship, civil government (Fearnside, 1990, 2000, 2006). First, there was the rapid growth of wood exploitation and forest clearance in the former colonised areas. Second, there was massive jungle clearance for the expansion of agriculture and cattle ranching using slash and burn. Third, there was the expansion of areas of settlement to cope with intense migration. At the end of the 1980s, these problems had grown more serious, particularly in the states of Pará and Rondônia (Martine, 1990), arousing national and international attention (Fearnside, 1990, 2000, 2006; M. A. Monteiro, 2005).

During the Brazilian dictatorship period, the state of Pará experienced two phases of rural social mobilisation. The first cycle started at the end of the 1970s and was a long phase of grassroots mobilisation followed by a struggle to control existing Workers' Unions (Tura, 1996). The Catholic Church developed the rural workers' consciousness of social groups working together in an organized manner to overcome issues of land and rights as part of citizenship in the regional society. The first focal point was to conquer the Workers' Unions. They were considered the main political space for rural producers, peasants, and/or landless peasants. In Amazonia many Workers' Unions were created between the 1960s and the 1970s as part of an official apparatus to put rural workers under government rules and control. Until the middle of the 1980s, most Workers' Unions were controlled by large landowners and merchants and were designed for social assistance rather than workers' representation. The first cycle lasted until the late 1980s, by which time the movement was already in control of the majority of Workers' Unions and their federations.

The second cycle started when rural workers' social movement become more organised and aimed to link the labour structure to the pressing needs of their constituents. By identifying the needs of the peasantry, the rural workers' social movement was able to set a new agenda that was much more attractive to grassroots members and therefore increased popular participation in policymaking. As the rural workers' social movement become more organised and the political regime more democratic, workers were able to get significant concessions from the state. The combination of protest and negotiation is particularly well represented in the annual demonstrations that workers organise in the state and federal capital cities known as Gritos (meaning screams) (Faleiro \& Oliveira, 2005; R. Monteiro, 1996; Tura, 1996, 2000a).

Many of the Gritos took place in Pará during 1990-1995 and were motivated by several sociopolitical issues operating in the region: violence against leaders of rural smallholders, advocacy for agrarian reform, discontent with mega-projects like hydroelectric dams, fighting for better conditions 
in the rural area like roads, electricity, and changes in financial credit policy (F. A. Costa, 2000; Faleiro \& Oliveira, 2005; Tura, 2000b; M. Vasconcellos, 2009).

The greatest achievement of the rural workers during the second cycle, however, was the creation of a new form of rural credit designed to meet the needs of the poorest peasants in the region initially called as FNO - Rural Especial and later called PRONAF (Faleiro \& Oliveira, 2005; M. Vasconcellos, 2009). However, the benefits of PRONAF as a model that might be linked to sustainable development were questioned, citing a lack of concern about the environment (Haddad \& Rezende, 2002). Additionally, studies on responsibility for forest devastation have demonstrated that small-scale, family-based agriculture contributed greatly to Amazonian deforestation (Homma, 1998). Conservationist groups have defended the concept that existing fiscal means could be shaped to favour conservation (Haddad \& Rezende, 2002) rather than increasing "traditional agricultural production" (Hall, 2000, p. 99).

Amidst such controversies the approach of productive conservation emerged between NGOs and research institutes (Hall, 2000). Using the concept of the agroforestry system, this approach argues that environmental resources-users should be involved in the process of environmental management. This is the only way to effectively achieve sustainability. The experience of the use of agroforestry systems in closed areas of conservation (conservation units) has led to a proposal to apply a similar system in open areas under the management of the rural population (Hall, 2000).

Then, in 2000, the rural social movement had the idea of a project to combine production with conservation. In that year, when discussing the strategies of the Grito da Amazônia 2000 (2000 Amazonia Scream), the Workers' Union Federations debated the needs of the Proambiente, and from then on the idea developed further. The Proambiente is to link financial credit and production with the conservation of environment, thus creating a financial incentive to reduce the devastation of the forest. It is important to point out that the Proambiente programme is a proposal that emerged from inside the social movement's struggle for credit policy reform (Faleiro \& Oliveira, 2005; M. Vasconcellos, 2009).

The Proambiente advocated the enlargement of the credit policy to Amazonia and to include other mechanisms to foster the initiative of "productive conservation" (Hall, 2000, p. 99) through "remuneration of environmental services" (MMA, 2003, p. 2). Instead of being exclusively a credit policy for production, the proposal of the Proambiente was to incorporate issues of the environment in the process in order to support (as a priority) the rural producers who could combine production with the conservation of the environment (MMA, 2003).

Taking into account the influence of the social movement on government decision making, the Proambiente concept grew in stature when President Lula da Silva took power in 2003. The idea of the Proambiente arose in 2000 during discussions between the Federations of Agricultural Workers of Amazonia. The Proambiente thus emerged under the influence of a social movement carried out by rural workers' organisations and the recognition of its demands with the government that took power in 2003 (Faleiro \& Oliveira, 2005; M. Vasconcellos, 2009).

The Proambiente has been considered the major initiative to provide rural producers with financial incentives to reduce deforestation (Hall, 2004). The federal government used the proposal and has transformed the programme in public policy with financial incentives through which Pagamento por Serviços Ambientais - PES (Payment for Environmental Services) is linked to forest management by the local population (Fearnside, 2000; Oliveira \& Altafin, 2008). Family-based and small-scale producers engage in conservation activities, including the cultivation of permanent tree crops and reforestation. They receive subsidized loans and compensation payments through an environmental service fund (Fundo de Serviço Ambiental).

As the evolution of credit forms show, there are changes in the use of fiscal mechanisms within Brazil; primarily to aid family-based and small-scale producers and secondarily to internalise productive conservation as a way to achieve sustainable development and sustainable livelihoods. 
Such changes, however, are not the exclusive proposals of the federal government; rather they are outcomes of the proposals of the rural social movement that defends the desires and needs of the local, rural population.

The organisations that support the creation of the Proambiente gained power in the Lula da Silva period. Using their influence, they submitted the Proambiente proposal to the federal government and recommended its implementation as public policy (Faleiro \& Oliveira, 2005).

For development to be sustainable, it requires the active involvement of the people themselves in the design and implementation of activities planned to improve their interests. The emergence of sustainability as a goal for agriculture and development has stimulated increasing interest in understanding ecological processes within agricultural productivity and reducing negative environmental impacts of agricultural activities (Power \& Kenmore, 2002). In spite of the difficult reconciliation of conservation and development objectives (Pollini, 2011), experiences in a variety of countries have shown that participatory approaches to research and development, with innovative modes of interaction and mutual learning among farmers, scientists and technical personnel, can effectively develop sustainable agriculture (Pretty, 2002) and community-based natural resource management (Gruber, 2010).

Taking into account the experiences of the management of Conservation Units (Unidades de Conservação [UC]) and the Integrated Environmental Management Plan (Gerenciamento Ambiental Integrado), the Proambiente proposal incorporates popular participation and people-centred needs and priority approaches in its implementation (A. M. A. Vasconcellos, 2010). It presents platforms at state and local levels that encourage participatory planning through new forms of interaction to negotiate the use of resources linked to the concept of governance.

Governance emerges as a new theme in development cooperation, defined as a reform strategy, and a particular way to strengthen the institutions of civil society with the objective of making them more accountable, open, transparent, and democratic (Cooke, 2004; Gaventa, 2004). This brings older concepts of stakeholders' rights and public accountability together with recent interpretations of citizenship and policy (Gaventa \& Valderrama, 1999). As Agranoff and McGuire (2003) argue, governance is a process of facilitating and operating in multi-actor arrangements to solve problems that cannot be solved, or solved easily, by single actors. Crook (2003) argues that the degree of responsiveness to the poor and the extent to which there is an impact on poverty are determined primarily by the politics of local-central relations and the general regime context. The translation of good government into better lives for the poor is expected to happen via the mediation of civil society.

As Toner and Franks (2006) indicate the process of participation is one of the sustainable livelihood issues to play an active role in social intervention. These issues have been debated with respect to people-centred (bottom-up) approaches to development management. The process of participation also becomes linked with the establishment of rural livelihood development implemented by donors and governmental development agencies through development programmes and projects (IUCN, 2008; McGee, 2002; Petrini \& Pozzebon, 2010). The central issue of people's participation as an active process of direct involvement in the political structures that govern national life first emerged through the debates on bottom-up (Bowyer, 2005).

As Bouwen and Taillieu (2004) note, participation becomes interactive participation, in which people participate in the development and implementation of plans, by discussion and contributing to solutions. It means that best practice is put forward under shared decision making and selfdetermination as levels of participation. Shared decision making implies that interested parties not only intervene in planning, but also become partly responsible for the outcomes (Bouwen \& Taillieu, 2004). As Uphoff and Krishna (2004) argue, the more local communities are empowered to achieve their priorities, the more power the plan has to achieve its goals. However, empowerment based on power to offers an understanding that power is only a personal attribute (Nelson \& Wright, 2001) unconnected to political space. Concentrated on projects, power to offers an understanding that social 
change can be accomplished from an evolutionary process of people learning to become aware of power dynamics (Tembo, 2003; Vasconcellos \& Vasconcellos, 2009a).

The strategies and decision making networks reflect and preserve current privileges, perpetuating inequalities and social exclusion (Gilchrist, 2004). Community development usually operates within political systems where workers can be persuasive either because of their position in the networks or because of their professional status (Lebel, Mungkung, Gheewala, \& Lebel, 2010). Therefore, it is implied that specialists in this field must acknowledge their own influence while working to reduce power differentially (Gilchrist, 2004).

\section{The Proambiente Action at Local Level}

A major limitation of most development agencies and their programmes is the notion that the institutions should provide at the community level the technology, information, and knowledge seen as effective strategies of reducing development gaps (Oakley, 1995). The challenge is how to incorporate issues of culture and knowledge into a policy of community development that can be applied in different settings.

Although a number of issues were debated with the beneficiaries of the pole of Rio Capim within Proambiente programme, the researchers felt that some issues could be further explored, to add into discussions aspects of various groups' priorities (such as both male and female agriculturists, community leaders, younger people, and older people). As argued by Flynn (1992), everyone has the right to command their own destiny and certain decisions require expert knowledge; meaning that the experts themselves should be involved in the decision-making process. However, what the field work showed was that rather than being interested in actively taking part in decision making, people want to have strong leaders that know how to rule and that are able to make decisions on their behalf (Mutebi, 2004). It's a contradiction in the implementation of the participatory approach.

However, despite the importance of creating leaders in the local communities, there are some problems with the idea that leaders can make decisions in the name of local people (Oakley, 1995). As was argued by Melluci (1996), local people create informal networks to avoid central control mechanisms, and are seen as content to operate with high levels of autonomy and low formal accountability. In the case of Rio Capim pole, the informal networks that operate at the local level are more influential than local leaders in making the project achieve its aims.

Although the unit of family production (this is a programme category to define the area where a family lives and works) is an important issue for analysing cultural, social, and economic resources produced for generations, different characteristics emerge as result of cultural identity and knowledge production. This is because local people's interests in the pole of Rio Capim are also linked to the type of knowledge and skills that people have and that has been produced for generations. In fact, local people's knowledge and skills are the result of interaction between forms of natural resource use and the cultural attributes of the different groups that pursue a diversity of identity (Mosse, 2001).

Despite the fact that most local people directly depend on agriculture, they are still engaged in other economic activities that are linked to the exploitation of natural resources and skills gained from their knowledge and experiences. The unit of family production is based on the diversity of the production sub-system. However, community people want to deal with their demands and needs immediately, and say that they cannot wait for a long-term project results.

Five years into the programme at the pole of Rio Capim, the climate of expectation continues between the community and the Proambiente staff, and even within the community. The programme has failed to base its line of reasoning on premises that are acceptable to the majority of community members, and a tense relationship has led to a number of confrontations in public meetings. The attempt to convince the local, traditionally agrarian population to adopt other activities can be an 
alternative to Proambiente achievements. However, an orientation on common economic practice has little chance of success. Local people from the pole of Rio Capim have been traditionally involved in family agriculture practices. This is an area of fertile gallery forests, which are the most suitable areas for growing cash crops. Even in areas of assentamento (human settlement), the alternative offered is problematic because they need to address elementary concerns such as land registration and other support to give people the incentive to stay on their lands. This stresses the gap between what has been planned at the macro level and what people have demanded at the community (local) level.

The project carried out by Proambiente in Rio Capim proposes the introduction of new economic activities such as beekeeping, fish farming, and horticulture. These are considered by Proambiente as good alternatives to increase the incomes of local people. However, local people still want to carry out their traditional activities. Although the Proambiente is still encouraging agricultural methods that use new production technologies, at present the programme has advocated the inclusion of other projects including honey production and fish farming. Although the project has encouraged the incorporation of other economic activities in this pole, these proposed productive activities are dissociated from the cultural identity of the family.

This is an identity based on collective work, self-help, and effective participation of women in productive activities. The introduction of projects such as honey production and fish farming has been criticised, mainly by women's groups. Despite this, these projects are presented to communities as a method to increase local people's income, and to introduce other projects that are not family-based. The new economic activities were not competitive with the existing alternatives, which the project sought to restrict. The main source of livelihoods in Rio Capim is agriculture, based on the cultivation of maize (corn), bananas, rice, and manioc. The last two crops are produced in areas of the old land occupancies. They represent the most important source of income for the majority of households. The issues above are especially critical in the Proambiente, which require a host of new management skills to be deployed by local stakeholders and where complex issues of community identity and common pool resources management must be addressed (Brockington et al., 2008). At present, it is still disputable whether Proambiente works and provides benefits to local people.

The examples of the families in Vila do Galho (Rio Capim pole) identifies that the roles among men, women, and children are well-defined according to local rules socially constructed for multiple generations. Even where this self-consciousness is cultural rather than formal, it must be taken into account. Social and economic roles of men and women are dependent on their needs and priorities according to the degree of access to resources and participation in decision making. In both cases, women's participation depends on beliefs and the degree of skills in each setting.

The research identified that male and female labour (family units) have the same weight as a factor of production. The level of access to resources and participation in decision making processes is different but it is in balance with family planning. The rural family is structured according to knowledge that is socially constructed and the rules established in family groups. Although local people are engaged in courses, training, and other orientation from development agencies, they ask to follow the right period for cultivation and harvest (calendário agrícola) that resonates with local beliefs.

Participation in the Proambiente design has brought about a significant change in the communities' social practices. The research that supported this paper identified that local people have been encouraged to discuss between themselves ways to reduce the impacts of their economic activities on stocks of natural resources; trying to reconcile conservation and development objectives (Pollini, 2011). For example, in Vila do Galho, local people emphasise the significance of these environmental resources for the continued existence of their communities, for income generation, and for their families' food supply. From participation in the Proambiente design, core awareness about the environment has been instilled. People recognise that they need to preserve their natural resources to enable new generations to use them. The critical issue is that they currently depend on these same resources to supply their socio-economic needs. 
Fieldwork identified that through the use of participatory approaches, local people are able to combine their accumulated knowledge from close interaction with the environment. For example, communities were able to create figures showing how they divide and use their lands and what types of practices are more suitable for each area. Participatory approaches applied by Proambiente have contributed to local people's understanding of diverse cultural identities and local knowledge resources produced for long generations. Local people can understand that such diversity is part of the dynamics of society and that the existence of the different groups' identities, priorities, and knowledge resources result from the interactions that they develop in direct contact with the environment. However, what they were not able to understand is that they have been involved in a contradictory process of change that may negatively affect their lives and may even be contrary to their own interests.

For instance, Proambiente uses the dominant idea of community as homogeneous and applies the concepts of closed and open communities. In the sense of Proambiente, the communities are defined geographically and by their main production, which means according to the area where people live and what they produce (if communities' people work in fishing or agriculture activities). However, the concept of community for the Proambiente is oversimplified. The results of focus group assessment done by this research has shown that local people's concept of community is not only based on geographical and production patterns. The concept of community is much more complex and also involves elements of religion, forms of living, and social interaction.

The concept of community is involved in a social process that is not simply articulated in direct and immediate relations between people and environment but is historically constructed through all sorts of social practices. For instance, religion brings together people from different communities for collective work, independent of where they live or what they produce. Forms of living and social interaction are determined by their sense of family, of belonging to a group, although people from different communities interact among themselves. Local people work in a diversity of occupations simultaneously, such as crop cultivators, horticulturalists, fruit collectors, fisherman, and so on.

The people that arrived in the roadside colonies are chiefly from outside Amazonia and thus they are carriers of other regional cultures with adaptive systems different from the traditional Amazonian caboclos. Food habits, socialisation methods, worldviews, technical experience, and economic expertise all differ. The people who do not have registered lands join themselves to request land registration even if they are located in different geographical areas. Thus, the meaning of community cannot be seen as strict, but fluid and open to adjustment once configuration of the communities points to the fact that local people's livelihoods are involved in diverse socio-cultural practices. This shows that in spite of the use of participatory approaches, Proambiente does not view local people's interactions as strategies to secure the communities' own interests, to strengthen people and communities' relationships, or as ways to bring about changes in the implementation of the programme.

Participation and power relations are a critical issue in the Proambiente model. Fieldwork identified that land and financial credit have influenced the configuration of power. Taking the example of Rio Capim, the research identified that access to credit has been dominated only by those who have land registration. Credit policy was designed to be accessed by small-scale agriculturists; however it has not been adapted in light of changes. It is difficult to find local people who are happy with the forms of credit access. For example, in the pole of Rio Capim, local people have lived and worked there for long time but, predominantly, they do not have documented title to their land and thus cannot qualify for the available credit programmes.

This requires some changes in the definition of the criteria of access to credit. What the credit policy defines as results to be achieved is different from local people's view of the resources produced. While the former prioritises economic results, the latter is based on a model of environment conservation. If the Proambiente does not negotiate with banks for a new model of access to credit and results evaluation, it will be difficult for many families to access credit to carry out new forms of 
production. If rural communities do not have access to credit they will return to traditional forms of production based on slash and burn.

The research identified that there is a great gap between what was planned and what has been executed. As long as Proambiente does not take into account land registration and fails to clearly define the ways for environment services payment, the programme will not include new families, close its cycle of planning and expansion to new poles. This means that the incorporation of participation and the involvement of local communities in knowledge production are not sufficient. Although the programme uses the participatory approach in issues of project implementation to support and expand local production resources, the investment in external organisational cultures such as banks is an important issue to take into account. This is especially true when dealing with the existent power relationships between other organisations that interact at the local level.

Conflicts of interest in the use and occupation of land at the local level are other difficult tasks in the consolidation of Proambiente. The struggles for land require special attention when dealing with conflicts in defining areas of production and areas of conservation. This is particularly evident when certain rural communities do not want to take part in the programme because the programme incentivises and in some way imposes specific forms of production (Vasconcellos \& Vasconcellos, $2009 \mathrm{~b}$ ). This can create conflicts in the form of land use in rural production.

The fieldwork research has identified that local people are concerned that the programme will continue to overstress issues regarding forest conservation. However, productive conservation does not only mean natural resource conservation. Conversely, it means a way to reconcile forest management and development objectives. Local people want Proambiente to incorporate other land issues such as land reform, geographical demarcation, and registration; which are typical issues for community development. At the moment, local people emphasis that it is more important to prioritise legalization of land properties rather than to decide what should be produced. Taking into account that tenure security is a significant task in poverty reduction and a way for stimulating local development; the results of this research indicate that Proambiente should be the main vehicle to negotiate this issue with other government departments. If the programme positively negotiates tenure security, chances are that local people will gain greater confidence in the programme.

\section{Conclusion}

The history of the construction of Proambiente is an example of how local people gaining power can influence the development agenda. The results of the research show that Proambiente emerged as a requirement for a new model of public policy for the rural sector. This new model was a result of the struggles that the rural social movement carried out against regional and federal governments for the inclusion of poor rural communities in local and regional planning. Although social movements are part of the relationship of conflict between Government and rural society, they were a precondition for changes in public policy.

At the same time, the Proambiente example reveals a new way of governing to find more interactive methods between the state and local communities. In this case, the interactive engagements between the different organisations put into practice their activities at the local level and opened up the construction of new political space. The Proambiente case shows the importance of the intermediary NGO making a link between the local community (micro-level) and the federal Government (macrolevel). Although this is a space for introducing the importance of negotiation into the policy-making process, the nature of interaction and its outcomes need to be analysed in a specific context as well as the historical relationships that enabled the understanding of these interactions.

Additionally, the benefits of networking should be demonstrated over a long-term relationship. However, in spite of the criticism that the participation approach brings about, a key principle of 
community development is to ensure that participation in decision making is democratic, inclusive, and enables people to engage in the learning process through the involvement of the citizens in such a process. In spite of all the efforts to put the Proambiente programme into practice, it still requires the participation of civil society to debate the strategies created by government. The Proambiente has been a new and good process of governing. However, it has its own contradictions. In the Proambiente model, for instance, men, women, and youths have different levels of participation in decision making, although they have the same weight as factors of production.

As the concept of good governance becomes more widely accepted amongst politicians, policymakers, and the public, evidence is building about its practical significance. Attention is increasingly focusing on the relative roles and responsibilities of citizens and consumers, individuals and institutions, and local and national spaces, in translating statements of intent into practical actions. However, the term governance involves many ambiguities. Many governments, international agencies, researchers, and scholars are in agreement that the development of good governance is essential for eliminating a range of problems related to public administration, policy, and the community. The qualifying word good appears redundant since governance is expected to indicate a collection of features that contribute to a positive outcome.

The programme actions, through the NGO practices in Rio Capim, enabled individuals and groups to build the information that they needed to reach their targets and shed light on how they have constructed their social, cultural, and economic resources. It also supports an increase in local people's accountability for the whole development process. However, the information produced and the problems encountered need to be used to improve the programme's implementations in all aspects, including social issues; such as health, education, tenure, and land access. So far, the programme has given priority to increasing production in the context of forestry conservation. However, the key programme issue is to overcome the difficult reconciliation of environmental conservation and development objectives.

The interaction of Proambiente in the pole of Rio Capim has been positive. Under FANEP's intermediary organisation practices, this programme interacts at many levels to involve local people in the programme. However, one of the important conclusions is that interaction between government and local communities is a complex task that involves a range of different relationships at the local level. This indicates that programmes cannot be carried out only by one government department and particularly not by the Department of the Environment alone. This induces an imbalance in favour of the environment over social issues. In regions where social problems are high, social issues cannot be placed as secondary.

The research indicates that Proambiente and other similar programmes that pay individual families for environmental protection should not be conducted in isolation, but need to be supplemented by complementary programmes that address local people's needs, such as land registration services. Another conclusion is that local people's livelihood resources are connected, modelled, and mediated by power relations. The recognition that the expression of needs and priorities takes place in a context marked by power relations on the basis of cultural attributes is crucial to making any development programme effective. However, difficulties often arise in analysis of the space of interaction at local level policy actions and its impact on local people. The most evident manifestation of power is the route of changes from local people's demands to Proambiente aims and actions. However, more studies are needed to understand how power may be balanced in programmes sponsored and carried out by government. More research may help the understanding of how local people's demands may scale up and scale down without a loss of priorities.

From the use of participatory approaches, local people are able to demonstrate their livelihoods, resources and to debate their skills, abilities and knowledge that have been constructed for long generations. However, local people's expectations rise proportionally when they are asked to take part in an interactive process of participation. The experience shows that if a governmental programme aims to have a positive impact on social, cultural, political, economic, and environmental aspects, strategies should be developed for the specific situations in which the knowledge is created, structured, 
and used. If people's expectations are not answered with effective actions that bring direct benefit to local communities, then one could say the use of participatory approaches is a limited means of gaining information solely for government interests. This corroborates with the initial hypothesis that once local people's knowledge and demands are encompassed, state-sponsored programmes change local people's proposals to absorb their own development approaches. The state takes actions that do not prioritise people's demands. Thus, communities' priorities do not come first.

This paper shows that more action is also needed to intensify the interaction between governmental agencies and organisations that have been working alongside communities to achieve the production and conservation aims of the Proambiente programme. The challenge is to find a way to balance these activities so that one does not dominate the other. It will help to find ways to strengthen interactive participation to meet the basic needs of the rural communities and at the same time contribute to an awareness of the issues of forest management, all while taking into account rural people's knowledge and culture.

\section{Received 9 November 2010; received in revised form 4 November 2011.}

\section{References}

Agranoff, R., \& McGuire, M. (2003). Collaborative public management: new strategies for local governments. Washington, DC: Georgetown University Press.

Arce, A. (2003). Re-approaching social development: a field of action between social life and policy processes. International Development, 15(7), 845-861. doi: 10.1002/jid.1039

Becker, B. (2001). Revisão das políticas de ocupação na Amazônia: é possível identificar modelos para projetar cenários? Parcerias Estratégicas, 6(12), 135-159.

Berkhout, F., Verbong, G., Wieczorek, A., Raven, R., Lebel, L., \& Bai, X. (2010). Sustainability experiments in Asia: innovations shaping alternative development pathways? Environmental Science \& Policy, 13(4), 261-271. doi: 10.1016/j.envsci.2010.03.010

Booth, D. (2003). Bridging the macro - micro divide in policy-oriented research: two African experiences. In D. Eade (Ed.), Development methods and approaches - critical reflections (pp. 79-94). London: Oxfam.

Bouwen, R., \& Taillieu, T. (2004). Multi-party collaboration as social learning for interdependence: developing relational knowing for sustainable natural resource management. Journal of Community \& Applied Social Psychology, 14(3), 137-153. doi: 10.1002/casp.777

Bowyer, T. (2005). Public space, inequality and health: interaction and social welfare in rural Peru. International Relations, 19(4), 475-492. doi: 10.1177/0047117805058536

Brockington, D., Duffy, R., \& Igoe, J. (2008). Nature unbound: conservation, capitalism and the future of protected areas. London: Earthscan

Brum, A. (2005). Desenvolvimento econômico brasileiro. São Paulo: Vozes.

Bunker, S. G. (1985). Underdeveloping the Amazon. Urbana and Chicago: University of Illinois Press.

Chambers, R. (1992). Rural appraisal: rapid, relaxed and participatory [Discussion Paper $\mathrm{N}^{\text {o }} 311$ ]. Institute of Development Studies, Brighton, United Kingdom.

Chambers, R. (2005). Ideas for development. London: Earthscan. 
Clark, J. (1997). Policy influence, lobbying and advocacy. In M. Edwards \& D. Hulme (Eds.), Making a difference: NGOs and development in a changing world (pp. 191-202). London: Earthscan Publications.

Cooke, B. (2004). Rules of thumb for participatory change agents. In S. Hickey \& G. Mohan (Eds.), Participation: from tyranny to transformation? (pp. 42-56). New York: Zed Books.

Cornwall, A. (2002). Realizing rights: transforming approaches to sexual and reproductive wellbeing. London and New York: Palgrave and Zed Books.

Costa, F. A. (2000). Politicas publicas e dinâmica agrária na Amazônia: dos incentivos fiscais ao FNO. In L. R. Tura \& F. A. Costa (Eds.), Campesinato e estado na Amazonia (pp. 63-106). Brasilia: FASE.

Costa, F. A. (2005). O FNO e o desenvolvimento sustentável na Amazônia. In P. H. May, C. Amaral, B. Millikan, \& P. Ascher (Eds.), Instrumentos econômicos para o desenvolvimento sustentável na Amazônia brasileira (pp.49-60). Brasília: MMA.

Costa, J. M. M. da (1997). Desenvolvimento sustentável, globalização e desenvolvimento econômico. In T. Ximenes (Ed.), Perspectivas de desenvolvimento sustentável (pp. 65-78). Belém: NAEA/UFPA.

Crook, R. (2003). Decentralisation and poverty reduction in Africa: the politics of local - central relations. Public Administration and Development, 23(1), 77-88. doi: 10.1002/pad.261

Edwards, M., \& Hulme, D. (1997). Scaling-up the development impact of NGOs: concepts and experiences. In M. Edwards \& D. Hulme (Eds.), Making a difference: NGOs and development in a changing world (pp. 13-27). London: Earthscan Publications.

Edwards, M., \& Hulme, D. (2000). Scaling up NGO impact on development. In J. Pearce (Ed.), Development, NGOs and civil society (pp. 44-63). Oxford: Oxfam.

Faleiro, A., \& Oliveira L. R. de (2005). Proambiente: conservação ambiental e vida digna no campo. In P. H. May, C. Amaral, B. Millikan, \& P. Ascher (Eds.), Instrumentos econômicos para o desenvolvimento sustentável na Amazônia brasileira (pp. 69-76). Brasília: MMA.

Fearnside, P. M. (1990). Environmental destruction in the Brazilian Amazon. In D. Goodman \& A. Hall (Eds.), The future of Amazonia: destruction or sustainable development? (pp. 130-154). London: Macmillan.

Fearnside, P. M. (2000). Deforestation impacts, environmental services and the international community. In A. Hall (Ed.), Amazonia at the crossroads: the challenge of sustainable development (pp. 11-24). London: University of London.

Fearnside, P. M. (2005). Deforestation in Brazilian Amazonia: history, rates and consequences. Conservation Biology, 19(3), 680-688. doi: 10.1111/j.1523-1739.2005.00697.x

Fearnside, P. M. (2006). Desmatamento na Amazônia: dinâmica, impactos e controle. Acta Amazônica, 36(3), 395-400. doi: 10.1590/S0044-59672006000300018

Feuerstein, M.-T. (1986). Partners in evaluation. Evaluating development and community programmes with participants. London: Macmillan.

Flynn, D. J. (1992). Information systems requirements: determination and analysis. London: McGrawHill. 
Fowler, A. (2002). Assessing NGO performance: difficulties, dilemmas and a way ahead. In M. Edwards \& A. Fowler (Eds.), NGO management (pp. 293-307). London: Earthscan Publications.

Gaventa, J. (2004). Towards participatory governance: assessing the transformative possibilities. In S. Hickey \& G. Mohan (Eds.), Participation: from tyranny to transformation? Exploring new approaches to participation in development (pp. 25-41). New York: Zed Books.

Gaventa, J., \& Valderrama, C. (1999). Participation, citizenship and local governance. [Backgroud note prepared for workshop Strengthening participation in local governance, IDS Working Paper]. Institute of Development Studies. Brighton, United Kingdom

Gilchrist, A. (2004). The well-connected community. Bristol: Community Development Foundation.

Gregory, A. (2000). Problematizing participation: a critical review of approaches to participation in evaluation theory. Evaluation, 6(2), 179-199. doi: 10.1177/13563890022209208

Gruber, J. S. (2010). Key principles of community-based natural resource management: a synthesis and interpretation of identified effective approaches for managing the commons. Environmental Management, 45(1), 52-66. doi: 10.1007/s00267-008-9235-y

Guba, E. G., \& Lincoln, Y. S. (1989). Fourth generation evaluation. London: Sage Publications.

Guijt, I., \& Gaventa, J. (1998). Participatory monitoring \& evaluation: learning from change. [IDS Policy Briefing 12]. Institute of Development Studies. Brighton, United Kingdom.

Haddad, P., \& Rezende, F.(2002). Instrumentos econômicos para o desenvolvimento sustentável da Amazônia. Brasília: Ministério do Meio Ambiente.

Hall, A. (1991). Developing Amazonia: deforestation and social conflict in Brazil's Carajás programme. Manchester: Manchester University Press.

Hall, A. (2000). Environment and development in Brazilian Amazonia: from protectionism to productive conservation. In A. Hall (Ed.), Amazonia at the crossroads: the challenge of sustainable development (pp. 99-114). London, UK: Institute of Latin-American Studies.

Hall, A. (2004). Extractive reserves: building natural assets in the Brazilian Amazon [Working Paper Series $\mathrm{N}^{\mathrm{o}}$ 14]. Political Economy Research Institute, Massachusetts, USA.

Hall, A. (2008). Better RED than dead: paying the people for environmental services in Amazonia. Philosophical Transactions of the Royal Society, 363(1498), 1925-1932. doi: 10.1098/rstb.2007.0034

Homma, A. K. (1998). Amazônia: meio ambiente e desenvolvimento agrícola. Brasilia: EMBRAPASPI.

International Union for Conservation of Nature. (2008). Participatory monitoring and evaluation guidelines: for learning and adaptive management in LLS geographic components and landscapes. [Working draft version 6th]. International Union for Conservation of Nature. Gland, Switzerland.

Lebel, L., Mungkung, R., Gheewala, S. H., \& Lebel, P. (2010). Innovation cycles, niches and sustainability in the shrimp aquaculture industry in Tailand. Environmental Science \& Policy, 13(4), 291-302. doi: 10.1016/j.envsci.2010.03.005

Martine, G. (1990). Rondônia and the fate of small producers. In D. Goodman \& A. Hall (Eds.), The future of Amazonia: destruction or sustainable development? (pp. 179-225). London: Macmillan. 
Mayoux, L., \& Chambers, R. (2005). Reversing the paradigm: quantification, participatory methods and pro-poor impact assessment. Journal of International Development, 17(2), 271-298. doi: $10.1002 /$ jid.1214

McGee, R. (2002). Knowing poverty: critical reflections on participatory research and policy. London: Earthscan Publications.

Mejía, A. (2004). The problem of knowledge imposition: Paulo Freire and critical systems thinking. Systems Research and Behavioural Science, 21(1), 63-82. doi: 10.1002/sres.558

Melluci, A. (1996). Challenging codes: collective action in the information age. Cambridge: Cambridge University Press.

Milani, C. R. S. (2008). O princípio da participação social na gestão de políticas públicas locais: uma análise de experiências latino-americanas e europeias. Revista de Administração Pública, 42(3), 551-579. doi: 10.1590/S0034-76122008000300006

Ministério do Meio Ambiente. (2003). Proambiente: projeto do proambiente. Brasilia: GTA. Retrieved May 22, 2008, from http://www.gta.org.br/projetos_exibir.php?projeto=4

Ministério do Meio Ambiente. (2005). Proambiente: Plano de utilização da unidade de produção. Brasília: MMA.

Monteiro, M. A. (2005). Meio século de mineração industrial na Amazônia e suas implicações para o desenvolvimento regional. Estudos Avançados, 19(53), 187-207. doi: 10.1590/S010340142005000100012

Monteiro, R. (1996). Informação e redes de integração no novo ciclo de mobilizações dos pequenos agricultores da Transamazônica. Belém: UFPA.

Mosse, D. (2001). People's knowledge, participation and patronage: operations and representations in rural development. In B. Cooke \& U. Kothari (Eds.), Participation: the new tyranny? (pp. 1635). London and New York: Zed Books.

Mutebi, F. (2004). Reassessing popular participation in Uganda. Public Administration and Development, 24(4), 289-304. doi: 10.1002/pad.309

Nelson, N., \& Wright, S. (Eds.). (2001). Power and participatory development: theory and practice. London: ITDG Publishing

Oakley, P. (1995). People's participation in development projects. Oxford, United Kingdom: INTRAC.

Oliveira, L. R. de, \& Altafin, I. G. (2008). Proambiente: uma política de pagamento de serviços ambientais no Brasil. Rio Branco: XLVI SOBER.

Patton, M. Q. (2001). Qualitative research and evaluation methods. California: Sage Publications.

Petrini, M., \& Pozzebon, M. (2010). Integrating sustainability into business practices: learning from Brazilian firms. Brazilian Administration Review, 7(4), 362-378. Retrieved from http://www.scielo.br/pdf/bar/v7n4/04.pdf. doi: 10.1590/S1807-76922010000400004

Plummer, R., Velaniskis, J., Grosbois, D. de, Kreutzwiser, R. D., \& Loe, R. de (2010). The development of new environmental policies and processes in response to a crisis: the case of the multiple barrier approach for safe drinking water. Environmental Science \& Policy, 13(6), 535548. doi: 10.1016/j.envsci.2010.05.004 
Pollini, J. (2011). The difficult reconciliation of conservation and development objectives: the case of the Malagasy environmental action plan. Human Organization, 70(1), 74-87.

Power, A. G., \& Kenmore, P. (2002). Exploiting interactions between planned and unplanned diversity in agroecosystems: what do we need to know? In N. Uphoff (Ed.), Agroecological innovations: increasing food production with participatory development (pp. 233-242). London: Earthscan.

Pretty, J. (2002). Social and human capital for sustainable agriculture. In N. Uphoff (Ed.), Agroecological innovations: increasing food production with participatory development (pp. 47-57). London: Earthscan.

Rebien, C. C. (1996). Participatory evaluation of development assistance: dealing with power and facilitative learning. Evaluation, 2(2), 151-172. doi: 10.1177/135638909600200203

Rodriguez, J. P., Taber, A. B., Daszak, P., Sukumar, R., Valladares-Padua, C., Padua, S., Aguirre, L. F., Medellín, R. A., Acosta, M., Aguirre, A. A., Bonacic, C., Bordino, P., Bruschini, J., Buchori, D., González, S., Mathew, T., Méndez, M., Mugica, L., Dobson, A. P., \& Pearl, M. (2007). Globalization of conservation: a view from the South. Science, 317(5839), 755-756. doi: $10.1126 /$ science. 1145560

Santos, R. (1980). História econômica da Amazônia. São Paulo: TAQ.

Tembo, F. (2003). Participation, negotiation and poverty: encountering the power of images: designing pro-poor development programmes. Reading: Ashgate.

Tendler, J. (1997). Good government in the tropics. Baltimore: Johns Hopkins University Press.

Toner, A., \& Franks, T. (2006). Putting livelihoods' thinking into practice: implications for development management. Public Administration and Development, 26(1), 81-92. doi: $10.1002 /$ pad.395

Tura, L. R. (1996). Gritos do campo: reconhecimento político e exercícios de cidadania no Pará (Dissertação de mestrado). Universidade Federal do Rio de Janeiro, Rio de Janeiro, RJ, Brazil.

Tura, L. R. (2000b). Atores sociais e suporte institucional dos projetos do FNO-Especial. In L. R. Tura \& F. A. Costa (Eds.). Campesinato e Estado na Amazônia (pp. 271-322). Brasília: Brasília Juridica and FASE.

Tura, L. R. (2000a). Notas introdutórias sobre os fundos constitucionais de financiamento e sua configuração na região norte. In L. R. Tura \& F. A. Costa (Eds.). Campesinato e Estado na Amazônia (pp. 29-46). Brasília: Brasília Juridica and FASE.

Uphoff, N., \& Krishna, A. (2004). Civil society and public sector institutions: more than a zero-sum relationship. Public Administration and Development, 24(4), 357-372. doi: 10.1002/pad.313

Uphoff, N., Esman, M. J., \& Krishna, A. (1998) Reasons for success - learning from instructive experiences in rural development. New Delhi: Vistaar Publications.

Vasconcellos, A. M. A. (2010) State-sponsored socio-environmental development programme in action: the case of the Proambiente programme (Amazônia, Brazil). Saarbrücken: VDM Verlag Dr. Müller.

Vasconcellos, M. Sobrinho (2009). Partnership for local development: the relationship between local organisations and government in two areas of North-East Pará, Amazonia, Brazil. Saarbrücken: VDM Verlag Dr. Müller.

Vasconcellos, M., \& Vasconcellos, A. M. A. (2009a). Parceria, empoderamento e desenvolvimento local. Interações, 10(2), 133-148. doi: 10.1590/S1518-70122009000200002 
Vasconcellos, M., \& Vasconcellos, A. M. A. (2009b). Participação e Desenvolvimento Territorial: reflexões a partir do Programa Proambiente. In G. M. Rocha, S. B. Magalhães \& P. Teisserenc (Eds.), Territórios de desenvolvimento e ações públicas (pp. 261-290). Belém: EDUFPA.

Wield, D. (2003) Tool for project development within a public action. In D. Eade (Ed.), Development methods and approaches: critical reflections (pp. 183-213). London: Oxfam. 